\title{
Pequi: a Brazilian fruit with potential uses for the fat industry
}

\author{
Andréa Madalena Maciel Guedes ${ }^{*}$, Rosemar Antoniassi and Adelia Ferreira de Faria-Machado \\ Embrapa Agroindústria de Alimentos, Av. das Américas 29501, Rio de Janeiro, Brazil
}

Received 27 June 2017 - Accepted 10 August 2017

\begin{abstract}
Pequi is a native fruit from Brazil, found in the Amazon, Caatinga, Cerrado and Atlantic Rain Forest regions. It is one of the main plants with great potential for sustainable use in Central Brazil. Among 16 species comprising Caryocar genus, three are highlighted: $C$. brasiliense, $C$. villosum, and $C$. coriaceum, of economic importance for families in small communities of Brazilian Cerrado. They are generally organized in cooperatives and use the leaves for preparing medicinal extracts, and the fruits for culinary purposes. When the sale of fresh fruits is reduced, they produce and commercialize fruit preserves, and liqueur products, as well as extract the oil. Harvesting of mature fruits after falling from the tree while keeping some fruits at the plant is the best way for its sustainable production. The internal mesocarp contains from 36 to $66 \%$ dry weight of oil having traditional culinary, medicinal and cosmetic uses. This oil has $60 \%$ of oleic acid and 35\% palmitic acid, thus suitable for industrial fat hardstocks. The presence of the triacylglycerols POO and POP makes the oil of interest for cosmetic and food industries. Both pulp and kernel oils have been studied for their health effects. By physical, enzymatic or chemical modification, the oil has shown potential uses as cocoa butter substitute and zero trans fat product.
\end{abstract}

Keywords: Caryocar sp / Pequi oil

Résumé - Le pequi : un fruit brésilien à potentiel pour l'industrie des corps gras. Le Pequi est un fruit indigène du Brésil, issu des régions de l'Amazonie, de la Caatinga, du Cerrado et de la forêt Atlantique. C'est l'une des principales plantes offrant un grand potentiel d'utilisation durable dans le centre du Brésil. Parmi les 16 espèces que compte le genre Caryocar, trois se distinguent (C. brasiliense, C. villosum et $C$. coriaceum) en raison de leur importance économique pour les familles de petites communautés de la région du Cerrado brésilien. Elles sont généralement organisées en coopératives et utilisent les feuilles pour préparer des extraits médicinaux et les fruits à des fins culinaires. Lorsque la vente de fruits frais est réduite, le pequi est commercialisé sous forme de fruits en conserve ou de liqueurs et de l'huile en est extrait. La récolte de fruits mûrs tombés de l'arbre tout en conservant des fruits à l'usine semble la meilleure voie pour une production durable. Le mésocarpe interne contient de 36 à $66 \%$ d'huile (en poids sec) traditionnellement utilisée à des fins culinaires, médicales et cosmétiques. Cette huile contient $60 \%$ d'acide oléique et $35 \%$ d'acide palmitique, aptes à être utilisés en tant que matières grasses industrielles. La présence de triacylglycérol POO et POP confère à l'huile un intérêt particulier pour les industries cosmétiques et alimentaires. Les huiles de pulpe et de noyau ont été étudiées pour leurs effets sur la santé. Par modification physique, enzymatique ou chimique, l'huile a montré des utilisations potentielles en tant que substitut de beurre de cacao produit sans acides gras trans.

Mots-clés : Caryocar / C. brasiliense / C. villosum / C. coriaceum / huile de pequi

\section{Introduction}

Pequi, also known as pequierim, pequiá, pequi-rasteiro, is a native fruit from Brazil, found in the Amazon, Caatinga, Cerrado and Atlantic Rain Forest regions (Caryocaraceae,

*Correspondence: andrea.guedes@embrapa.br
2017), and mostly distributed in the central and southeastern regions of Cerrado. It also occurs in other South American countries and in Central America (Fig.1).

The Brazilian Cerrado is the richest savanna in the world in terms of number of species and the second largest biome in Brazil, after Amazonia, comprising 21\% of the land area. It is mainly located in Central Brazil extending over several states, such as Goiás, Tocantins, Ceará, Mato Grosso, Minas Gerais, 


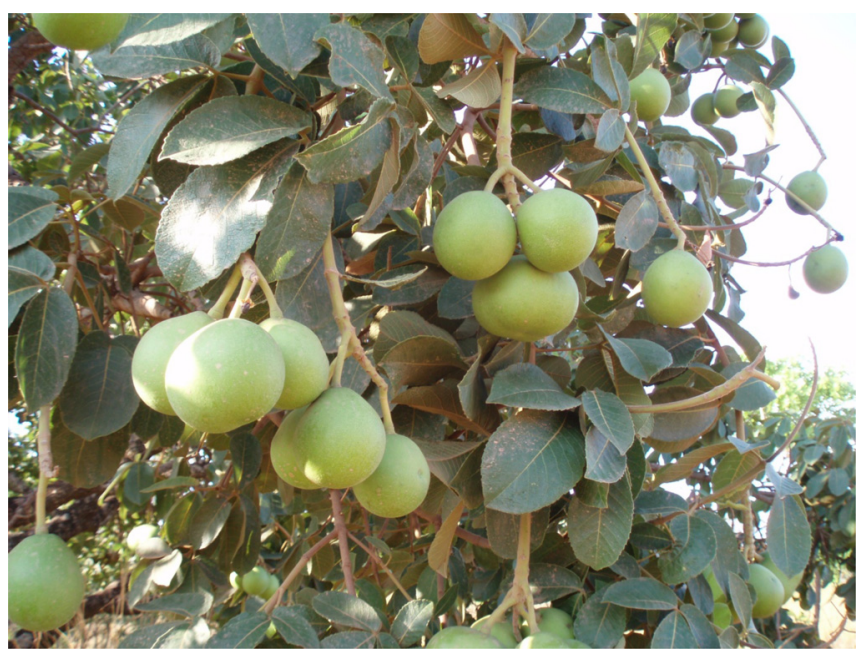

Fig. 1. Pequi tree and fruits (Photo: Nilton T. V. Junqueira).

and Pará. Endemism and human pressure turned this biome into one of the priority areas for conservation of biodiversity in the world (Oliveira and Scariot, 2010; Silva and Fonseca, 2016; Silva et al., 2001).

The fruit is cooked before consumption and the pulp is used in the preparation of several dishes. The most popular uses of pequi are in flavoring rice, chicken, and in homemade fruit preserves (Araujo, 1995; Silva and Fonseca, 2016). Homemade soaps are also produced when the fruit is not suitable for cooking. The kernel is used as an ingredient in preparations of roasted cassava or maize flour mixtures and fruit preserves, or is consumed as a salted snack. The pulp is rich in edible oil. The chemical composition of the oil has encouraged researchers to study its industrial applications in different products.

\section{Extractive production and general uses}

Pequi tree is a perennial slow growing tree with the ability to resprout and persist for a long period of heavy fruit harvesting pressure. Caryocar seed dispersal is limited due to the lack of long distance seed dispersers, which contributes to its total density. It occurs in $61 \%$ of the Cerrado, being well adapted to low fertility soils (Giroldo and Scariot, 2015).

Sixteen species of Caryocar L. genus have been reported, three of them of higher economic importance: Caryocar brasiliense, $C$. villosum, and $C$. coriaceum. The main product obtained from these species is the oil, which can be extracted from both the mesocarp and the kernel (Araujo, 1995).

The cutting and commercialization of its wood have been prevented by law, in Brazil, since 1987 (IBDF, 1987). Additionally, there are specific rules to protect Caryocar, such as the prohibition of harvesting fruit from the tree, i.e., before falling to the ground. Besides, farms have common areas of native vegetation preserved by law ("Legal Reserves") [Giroldo and Scariot, 2015]; however, there are fruit collectors who pick most of fruits of the tree, thus reducing its propagation (Leite et al., 2006).

It is a plant with great potential for sustainable development use in the central region of Brazil. It has an estimated average production of 7027 ton of fruits corresponding to $C$. brasiliense plus C. coriaceum (IBGE, 2011), an underestimated production based on official data. In Brazil, pequi is quite popular due to its culinary and therapeutic applications.

In the north area of Minas Gerais State, the second largest producer in terms of area of C. brasiliense, there is no homogeneous seeding. The fruits are collected from preserved areas. The harvesting is organized by cooperatives and generates income to 2400 small farmers' families. Pequi has not been domesticated and its production is therefore the result of extractivism. However, the awareness of some communities about biome preservation has led to the planting of seedlings. The price of the fruits changes depending on harvest quality, which in turns, depends on climatic factors, such as drought. A minimum price policy is applied to help preserving Caryocar species (CONAB, 2012).

Some technical assistance and rural extension companies support producers to increase tree propagating and prevent from disease and pests (CONAB, 2013, 2016).

Since the number of native pequi trees is not enough to meet the increasing demand, Embrapa is currently studying the possibility of cultivation. In this line, grafting as a method of vegetative propagation has been used for domestication, cultivation, and further propagation. With the help of this method, the productivity would increase from 2 ton per hectare ( 5 years after planting) to 40 ton per hectare by using suitable agronomic practices, which means 2.4 tons of oil per hectare, considering the sum of both pulp and kernel oil (Nilton Junqueira, personal communication, 2016).

Pequi plays an important role for local populations and industries, either ecologically and economically, through the exploitation of its fruits and kernels.

The mesocarp is thick, and divided into an external layer and an internal yellowish layer with a strong and distinct taste and smell. The endocarp is woody, muricate and spiny on the outside. The endocarp is about one sixth of the fruit weight, and the kernel is one third (Fig. 2). The flowering period usually occurs before and at the beginning of the rainy season, from June to September, with maturation lasting beyond the end of the rainy season, when dispersal of the seeds take place (Araujo, 1995).

\section{Oil composition}

Considering the main species of Caryocar, the chemical composition of pulp oil (36-66\% of fruit, d.b.) [Faria-Machado et al., 2015] and kernel oil (14-48\% w.b.) [Rogério et al., 2012 ] consists of palmitic (35-40\%) and oleic (55-60\%) as the major fatty acids (Facioli and Gonçalves, 1998; Guedes et al., 2017; Lima et al., 2007; Silva and Fonseca, 2016. The pulp oil has a high content of carotenoids up to $246 \mu \mathrm{g} / \mathrm{g}$ (Aquino et al., 2009).

The triacylglycerol composition may vary according to location for the same species and between species. The main triacylglycerols found in pulp oil are POP (1,3-dipalmitoyl-2oleyl-glycerol), POO (1,2-dioleyl-3-palmitoyl-glycerol), and POS (palmitoyl-oleyl-stearoyl-glycerol) [Facioli and Gonçalves, 1998; Guedes et al., 2017]. 

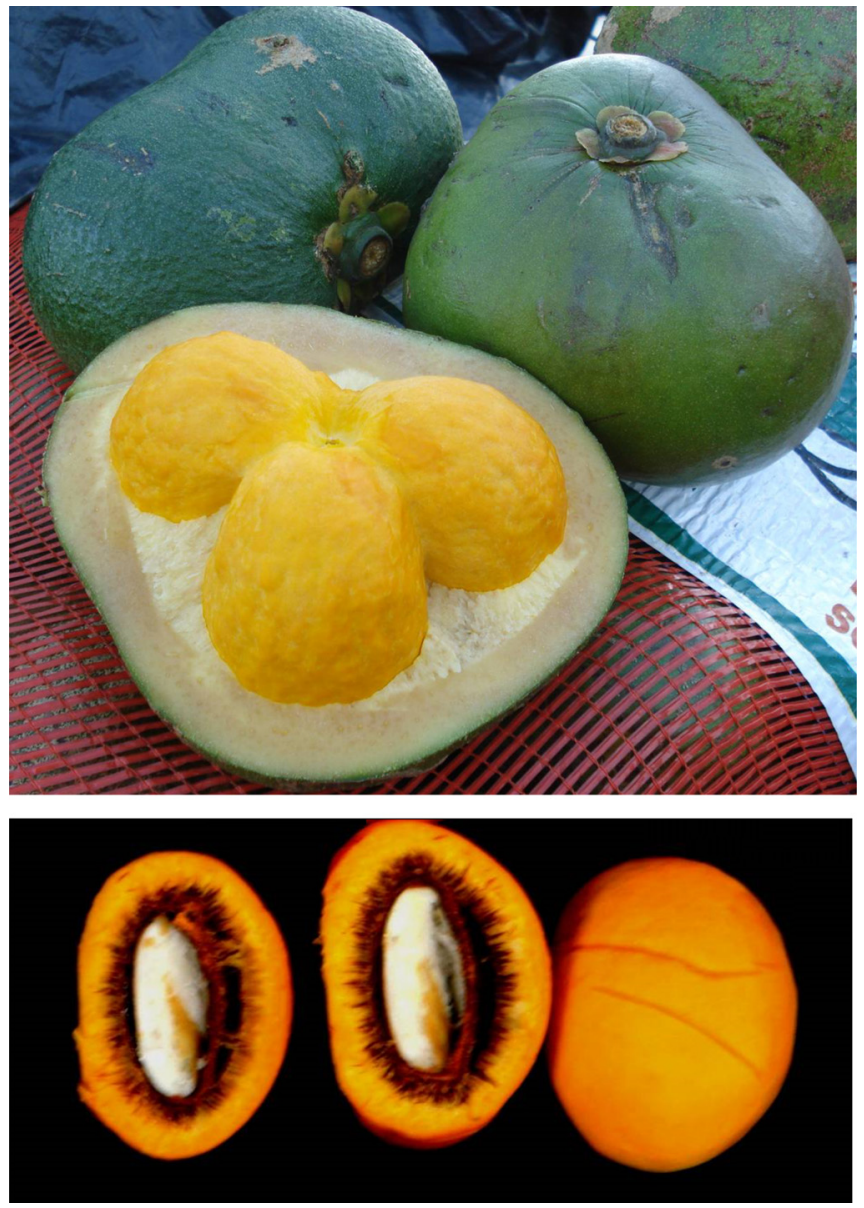

Fig. 2. Pequi Fruit (Photo: Nilton T. V. Junqueira).

Pequi oil has exhibited biological effects, such as antioxidant properties, due to the high carotenoid content of C. brasiliense pulp oil, which may slow atherogenesis in the initial stages (Aguilar et al., 2012). Wound and gastric healing effect of C. coriaceum oil has been reported (Quirino et al., 2009). Topical anti-inflammatory effect of $C$. coriaceum pulp and kernel oils was also demonstrated (Oliveira et al., 2010; Saraiva et al., 2011).

\section{Extraction methods}

The first collected fruits have higher quality and are sold in natura, mainly for use in culinary preparations. As long as its price is reduced, the fruits are used for oil production.

Endocarp plus internal mesocarp are boiled in water on a low fire and stirred until the oil is extracted. The oil rises to the surface, and is skimmed with a spoon. Since it is a rudimentary technique, the production of around six liters of oil can take up to two days (Oliveira and Scariot, 2010). Alternatively, the oil is carefully filtered to remove tiny thorns, and then heated to release excess water (Araujo, 1995).

The oil can also be extracted by solvents, such as acetone, ethanol, and hexane that must be eliminated in the final stage of processing. In this case, a previous drying of the pulp material is necessary. Oil yield and total carotenoid content are dependent on the solvent used, as well as the drying process
(Aquino et al., 2009, 2011). Mechanical extraction of the dried pulp followed by filtration has also been reported. However, the amount of carotenoids and quality properties of the oil are reduced (Ribeiro et al., 2012).

\section{Potential uses}

The high content of the monounsaturated fatty acid, around $60 \%$ of oleic acid, is interesting for food, cosmetic and oleochemical uses. Additionally, pequi oil contains around $35 \%$ palmitic acid (C16:0), which makes it suitable for margarine and shortening applications (Guedes et al., 2017). Both fatty acids can affect physical stability of the oil in tropical regions.

Despite showing lack of functionality for direct industrial use due to its physical properties, such as melting and crystallization behavior, the triacylglycerol composition reported by Guedes et al. (2017) indicates pequi oil as a good source of POP, enabling its application as cocoa butter substitutes.

Due to its fatty acid composition, pequi oil has a tendency to fractionate in storage. This issue can be eliminated by chemical interesterification, which produces a new zero trans fat with different applications in food fat industry, with new polymorphism, different crystallization and melting profiles, thus offering a wider range of functionality at room and cold temperatures (Guedes et al., 2017). In addition, the product obtained by this process is an alternative to fats rich in trans fatty acids whose negative effects are well documented (Mozaffarian et al., 2006).

The oil can also be enzymatically modified using Lipozyme in order to incorporate stearic acid in the sn-1,3 position of triacylglycerols and obtain a cocoa butter-like fat (Facioli and Gonçalves, 1998)

Homemade and cold pressed pequi kernel oils tested in vivo showed hepatoprotective effects, due to their antioxidant and anti-inflammatory properties (Torres et al., 2016).

The oil extracted from the kernel has a pleasant light smell and is used in the cosmetic industry, although the oil from the pulp has also been used for the same purpose (Battermann and Hippe, 2014; José Antonio dos Santos, personal communication, 2016).

Jelly capsules of aqueous and organic extracts of pequi claimed to induce antioxidant and antimutagenic effects were reported and have been marketed in Brazil (Grisólia et al., 2007).

Despite the high saturated fatty acids content, and the tendency to crystallize, the use of the oil as biodiesel has been investigated (Abreu et al., 2004; Borges et al., 2012).

\section{Conclusion}

Pequi pulp and kernel oils have similar fatty acid composition, with approximately balanced proportions of saturated and unsaturated fatty acids, contributing to their fractionation in storage in tropical regions. The oil is a source of POP, a triacylglycerol of great interest in food industry. Pequi pulp oil is also a specialty oil with the presence of bioactive compounds requiring further information. Sustainable cultivation of the plant and higher fruit production 
followed by improvements in extraction methods would increase oil production, and would certainly contribute to add value to its production chain.

\section{References}

Abreu FR, Lima DG, Hamúa EH, Wolf C, Suarez PAZ. 2004. Utilization of metal complexes as catalysts in the transesterification of Brazilian vegetable oils with different alcohols. $J \mathrm{Mol}$ Catal A: Chemical 209: 29-33.

Aguilar EC, Jascolka TL, Teixeira LG. 2012. Paradoxical effect of a pequi oil-rich diet on the development of atherosclerosis: balance between antioxidant and hyperlipidemic properties. Braz J Med Biol Res 45: 601-609.

Aquino LP, Ferrua FQ, Borges SV, Antoniassi R, Correa JLG, Cirillo MA. 2009. Influence of pequi drying (Caryocar brasiliense Camb.) on the quality of the oil extracted. Food Sci Technol (Campinas) 29: 354-357.

Aquino LP, Borges SV, Queiroz F, Antoniassi R, Cirillo MA. 2011. Extraction of oil from pequi fruit (Caryocar brasiliense, Camb.) using several solvents and their mixtures. Grasas Aceites 62: 245-252.

Araujo FD. 1995. A review of Caryocar brasiliense (Caryocaraceae) - an economically valuable species of the central Brazilian Cerrado. Econ Bot 49: 40-48.

Battermann M, Hippe T. 2014. Hair treatment agent useful for treating keratinous fibers comprises pequi oil, silicone comprising e.g. alkoxylated silicone, dimethicone, volatile silicone and/or sugarcontaining silicone, and aqueous- or aqueous-alcoholic carrier. Patent DE102013212618, 45 p.

Borges KA, Batista, ACF, Rodrigues HS, Terrones MH, Vieira AT, Oliveira MF. 2012. Current Problems. Alternative Fuels production of methyl and ethyl biodiesel fuel from pequi oil (Caryocar brasiliensis Camb.). Chem Technol Fuels Oils 48: 83-89.

Caryocaraceae, 2017. In: Flora do Brasil 2020 em construção. Jardim Botânico do Rio de Janeiro. Available from http://floradobrasil.jbrj. gov.br/reflora/floradobrasil/FB47900. (last consult: 2017/21/06).

CONAB, 2012. Conjuntura Mensal. Pequi (fruto). Available from http://www.conab.gov.br, Accessed June 2017.

CONAB, 2013. Conjuntura Mensal. Pequi (fruto) março 2013. Available from http://www.conab.gov.br/detalhe.php?c= 29501\&t=2\#this, Accessed June 2017.

CONAB, 2016. Conjuntura Mensal. Pequi abril 2016. Available from http://www.conab.gov.br/detalhe.php?c=40497\&t=2\#this, Accessed June 2017.

Facioli NL, Gonçalves LAG. 1998. Modificação por via enzimática da composição triglicerídica do óleo de piqui (Caryocar brasiliense Camb). Quím Nova 21: 16-19.

Faria-Machado AF, Tres A, van Ruth SM. 2015. Discrimination of pulp oil and kernel oil from pequi (Caryocar brasiliense) by fatty acid methyl esters fingerprinting, using GC-FID and multivariate analysis. J Agric Food Chem 63: 10064-10069.

Giroldo AB, Scariot A. 2015. Land use and management affects the demography and conservation of an intensively harvested Cerrado fruit tree species. Biological Conservation 191: 150-158.

Grisólia CK, Khouri J, Oliveira ABB, Resck IS, Miranda-Vilela AL. 2007. Cáspsulas gelatinosas de polpa de pequi (Caryocar brasiliense Camb.) como suplemento vitamínico, antioxidante e antimutagênico, um novo nutracêutico. Patent BR PI0601631-6, $7 \mathrm{p}$.

Guedes AMM, Antoniassi R, Galdeano MC. 2017. Length-scale specific crystalline structural changes induced by molecular randomization of pequi oil. J Oleo Sci 66: 469-478.

IBDF. 1987. Portaria n. 54, 3 mar 1987. DOU 13/03/1987-Pg. 35 - Seção 1 Diário Oficial da União.

IBGE, 2011. Instituto Brasileiro de Geografia e Estatística. 2011. [Internet]. Produção da extração vegetal e da silvicultura. Available from http://www.ibge.gov.br/home/estatistica/econo $\mathrm{mia} /$ pevs/2011/default xls.shtm. (last consult 2015/1/12).

Leite GLD, Veloso RVD, Zanuncio JC, Fernandes LA, Almeida CIM. 2006. Phenology of Caryocar brasiliense in the Brazilian Cerrado region. For Ecol Manage 236: 286-294.

Lima A, Silva AMO, Trindade RA, Torres RP, Mancini-Filho J. 2007. Composição química e compostos bioativos presentes na polpa e na amêndoa do pequi (Caryocar brasiliense, Camb) Rev Bras Frutic 29: 695-698.

Mozaffarian D, Katan MB, Ascherio A, Stampfer MJ, Willett WC. 2006. Medical progress - Trans fatty acids and cardiovascular disease. N Engl J Med 354: 1601-1613.

Oliveira WL, Scariot A. 2010. Boas práticas de manejo para o extrativismo sustentável do pequi. Brasília: Embrapa Recursos Genéticos e Biotecnologia.

Oliveira MLM, Nunes-Pinheiro DCS, Tome AR. 2010. In vivo topical anti-inflammatory and wound healing activities of the fixed oil of Caryocar coriaceum Wittm. seeds. J Ethnopharmacol 129: 214-219.

Quirino GD, Leite GD, Rebelo LM. 2009. Healing potential of Pequi (Caryocar coriaceum Wittm.) fruit pulp oil. Phytochemistry Letters 2: 179-183.

Ribeiro MC, Vilas Boas EVB, Riul TA, Pantoja L, Marinho HÁ, Santos AS. 2012. Influence of the extraction method and storage time on the physicochemical properties and carotenoid levels of pequi (Caryocar brasiliense Camb.) oil. Cienc Tecnol Aliment 32 : 386-392.

Rogério JB, Duarte ID, Santos MCS. 2012. Variação da composição dos ácidos graxos dos óleos de polpa e amêndoa de pequi. In: congresso da rede brasileira de tecnologia de biodiesel, 5; Congresso brasileiro de plantas oleaginosas, óleos, gorduras e biodiesel, 8. Salvador. Lavras: UFLA 1: 275-276.

Saraiva RA, Araruna MKA, Oliveira RC. 2011. Topical antiinflammatory effect of Caryocar coriaceum Wittm. (Caryocaraceae) fruit pulp fixed oil on mice ear edema induced by different irritant agents. J Ethnopharmacol 136: 504-510.

Silva AA, Fonseca GGE. 2016. Brazilian savannah fruits: Characteristics, properties, and potential applications. Review. Food Sci Biotechnol 25: 1225-1232.

Silva DB, Junqueira NT, Silva JÁ, Pereira AV, Salviano A, Junqueira GD. 2001. Avaliação do potencial de produção do "pequizeiroanão" sob Condições naturais na região sul do estado de minas gerais. Food Sci Biotechnol 23: 726-729.

Torres LRDO, Santana FC, Torres-Leal FL. 2016. Pequi (Caryocar brasiliense Camb.) almond oil attenuates carbon tetrachloride-induced acute hepatic injury in rats: Antioxidant and anti-inflammatory effects. Food and Chemical Toxicology 97: $205-216$. 